$$
\begin{aligned}
& \alpha \text {-フェトプロテイン産生肺癌の } 1 \text { 例 } \\
& \text { 弘前大学医学部第二内科 } \\
& \text { 早津 正文○ 盛 英機 井沢和弘 } \\
& \text { 仲里弘 小石陽一 山辺英彰 } \\
& \text { 大能 達義 金沢 武道 小野寺庚午 } \\
& \text { 弘前大学医学部第二病理（工藤一教授） } \\
& \text { 佐藤 達資 }
\end{aligned}
$$

\title{
A CASE OF A LUNG CANCER PRODUCING $\alpha$-FETOPROTEIN AND RIGHT HEMIPLEGIA DUE TO BRAIN METASTASIS AS A CHIEF COMPLAINT
}

Masahumi Hayatsu, MD, Hideki MoRI, MD, Masahiro IZAWA, MD,

Hiroshi NAKAZATO, MD, Yoichi KoIsHi, MD,

Hideaki YamaBe, MD, Tatsuyoshi OKuma, MD, Takemichi Kanazawa, MD, and Kogo ONODERA, MD

The Second Department of Internal Medicine, Hirosaki University School of Medicine, Hirosaki, Japan

Tatsusuke SATO, MD

The second Department of Pathology, Hirosaki University

School of Medicine, Hirosaki, Japan

概要 68 才の男性，会社員．主訴：右片麻瘦. 昭和54年 8 月頃上り右上肢の，同年11月頃上 り右下肢の麻疩がそれぞれ出現. 精査のため 12 月19日当科入院. 脳血管写, CTスキャン, 脳シ

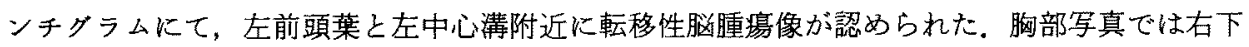

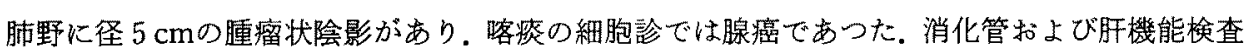
は正常であつたが，血中 $\alpha$-fetoproteinのみ $32 \times 10^{4} \mathrm{ng} / \mathrm{ml}$ と著しく高值を示した， 2 月に入り頭 痛，悪心，食欲不振を訴兄，IVH・化学療法などを行なつたが，5月 7 日呼吸不全のため死亡 した。経過中 $\alpha$-fetoprotein怔，常に $10000 \mathrm{ng} / \mathrm{ml}$ 以上を示した。剖検では右肺下葉原発の中等度 分化の腺癌で, 肝・脳・リンハ節などに転移が諗められた。癌組織を木モジネートして, RIA法 で測定すると，腺癌組織の $\alpha$-fetoprotein 237.6 ( $\mu \mathrm{g} / \mathrm{g}$ 湿重量)，肝癌組織43.8 (同)，リン八゙節 組織213.5 (同)で，対照肝組織0.86 (同) 飞比べ高值であつた。 $\alpha$-fetoprotein亿対する虽光抗 体法で，各癌組織とも陽性となり， $\alpha$-fetoproteinの局在を示唆した。 $\alpha$-fetoprotein陽性癌は，

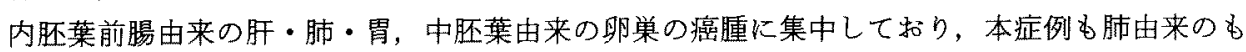
のであつた。本症例は脳症状を初発とした $\alpha$-fetoprotein産生肺癌であり，極めて希有な症例で あつ大.

[昭和57年 8 月 16 日受稿]

本論文は第103回日本内科学会東北地方会

（昭和56年 2 月 13 日）にて発表した。
はじめに

血清 $\alpha$-fetoprotein(AFP)は, Abelev ${ }^{1)}$, Tatarinovら 2)の研究に上り原発性肝細胞癌ならびに胎 児癌の際に特異的に高值になり，これらの疾患の 
診断に役立つと報告された。最近，AFP測定法の 進歩により検索対象例が増加し, 肝硬変や胃癌な どの消化器癌にもAFP高値のいわゆるAFP偽陽 性例防がみられるようになつた。一方, 肺癌の中に は種々のホルモンを産生したり，種々の活性物質 を産生したりする例がある4).

われわれは, 血清AFPの高値を呈した肺癌の症 例を経験したので, 血清AFPの由来についての検 討を加え報告する。

\section{症例}

患者：男性, 68才，商業。

主訴：右片麻痷。

現病歴： 昭和54年 8 月頃より, 字がうまく書 けなくなつた．同年11月下旬に自転車に乗つて転 倒し,その 1 週後に右下肢の不全麻痺が出現した. それ以来, 書字拙技症状は進行性に増悪したため, 某整形外科を受診し，末梢神経麻疸の診断をうけ た、治療をらけたが改善せず，12月19日当科に入 院した。

既往歴： 腹膜炎 (18才), 胸膜炎 (30才).

家族歴：父が脳卒中, 兄が肝癌にて死亡.

入院時現症：体格は中等大. 栄養は不良. 意 識清明. 脈拍 $60 / \mathrm{min}$ で整. 血圧は $152 \sim 76 \mathrm{mmHg}$. 結膜に貧血 (一), 黄疸 (一). 頝部リンパ節腫脹 はない, 心藏濁音界は正常, 心尖部にLevine 3 度 の収縮期雑音を聴取する。肺呼吸音は正常. 腹部 は扁平で肝・脾・腎は触知されない，各脳神経機 能は正常。右上下肢の不全麻盘がある。膝蓋腱反 射ならびにアキレス腱反射は右側は消失し，左側 は減弱。握力は右 $15 \mathrm{~kg}$, 左 $20 \mathrm{~kg}$. 知覚障害は認めら れない. 足クローヌス, バビンスキー反射は認め られない.

\section{検査成績}

1）一般臨床検査（表 I）：入院時軽度に負血 と血清低蛋白がみられた。しかし肝機能は正常で あつた。血清AFPは 1 月29日は10000 $\mathrm{ng} / \mathrm{ml}$ 以上, 3 月 11 日には $32 \times 10^{4} \mathrm{ng} / \mathrm{ml}$ と高値を示した。2) 胸部 X線写真 (図 1)：右下肺野の縦隔横隔膜陰 影の中に, 長径約 $5 \mathrm{~cm}$ の棈円形の腫瘤状陰影があ り.心胸郭比は $53 \%$. 3) 眼科的検查； 5 つ血乳

\section{表 1. 入院時検查成績}

\begin{tabular}{cc|cc} 
Urinalysis : n.p. & & Blood chemistry : \\
P. Blood : RBC & $354 \times 10^{4} / \mathrm{mm}$ & T.P & $5.6 \mathrm{~g} / \mathrm{dl}$ \\
$\mathrm{Hg}$. & $13.1 \mathrm{~g} / \mathrm{dl}$ & $\mathrm{Alb}$ & $3.6 \mathrm{~g} / \mathrm{dl}$ \\
$\mathrm{Ht}$. & $40.2 \%$ & $\mathrm{Na}$ & $145 \mathrm{mEq} / l$ \\
WBC & $4,000 / \mathrm{mm}$ & $\mathrm{K}$ & $3.9 \mathrm{mEq} / l$ \\
ESR & $5 / 12 \mathrm{~mm}$ & $\mathrm{Cl}$ & $110 \mathrm{mEq} / l$ \\
Serological test : & & $\mathrm{BUN}$ & $26 \mathrm{mg} / \mathrm{dl}$ \\
CRP & $(-)$ & $\mathrm{Cr}$ & $0.9 \mathrm{mg} / \mathrm{dl}$ \\
HB-Ag & $(-)$ & $\mathrm{GOT}$ & $30 \mathrm{U} / l$ \\
TPHA & $(-)$ & $\mathrm{GPT}$ & $33 \mathrm{U} / l$ \\
Liquor : & & $\mathrm{Al}-\mathrm{ph}$ & $76 \mathrm{U} / l$ \\
& & $\mathrm{LDH}$ & $240 \mathrm{U} / l$ \\
Pressure $180 \mathrm{mmHg}$ & $\gamma-\mathrm{GTP}$ & $24 \mathrm{U} / l$ \\
watery clear & $\mathrm{T} . \mathrm{Bil} .0 .3 \mathrm{mg} / \mathrm{dl}$ \\
Total Protein $57 \mathrm{mg} / \mathrm{dl}$ & $\mathrm{Ca}$ & $9.0 \mathrm{mg} / \mathrm{dl}$ \\
Glucose & $55 \mathrm{mg} / \mathrm{dl}$ & $\mathrm{CEA}: 3.0 \mathrm{ng} / \mathrm{ml}$ \\
Cl & $120 \mathrm{mEq} / l$ & $\mathrm{AFP}: 32 \times 10^{4} \mathrm{ng} / \mathrm{ml}$
\end{tabular}

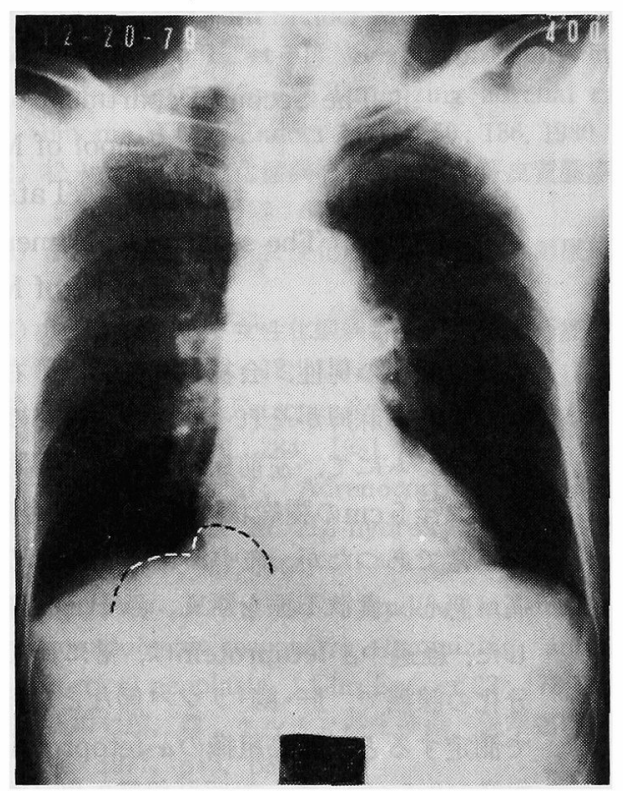

図 1。胸部 X線写真：右下肺野に長径約 $5 \mathrm{~cm}$ の棈 円形の腫瘤状陰影（破線部）あり。

頭ならびに視野の異常は認められない，4）脳の CTスキャン所見（図 2); 左前頭部之頭頂部の 2 力所に, 周辺low densityの約 $4 \mathrm{~cm} \times 4 \mathrm{~cm}$ の high density areaがそれぞれあり，造影剤によつてenhanceされた。左側脳室は圧排されていた５）脳 シンチ(図 3)：，左前頭葉領域に円形均質な約 4 


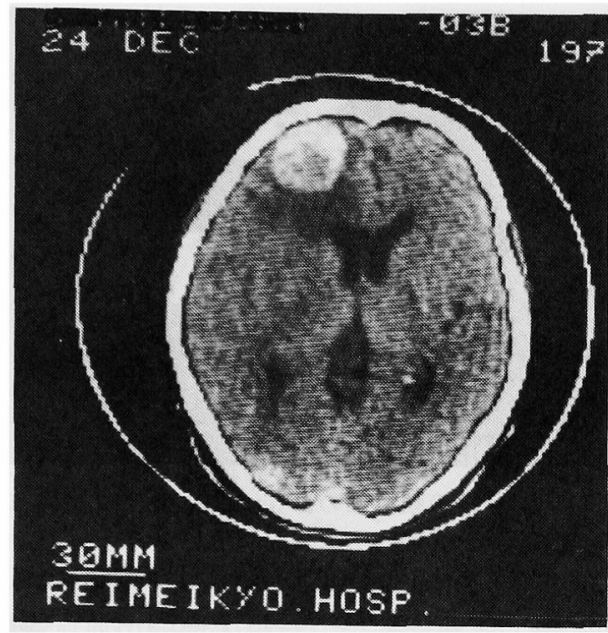

図 2. 脳のCTスキャン：左前頭部にhigh density areaあり.

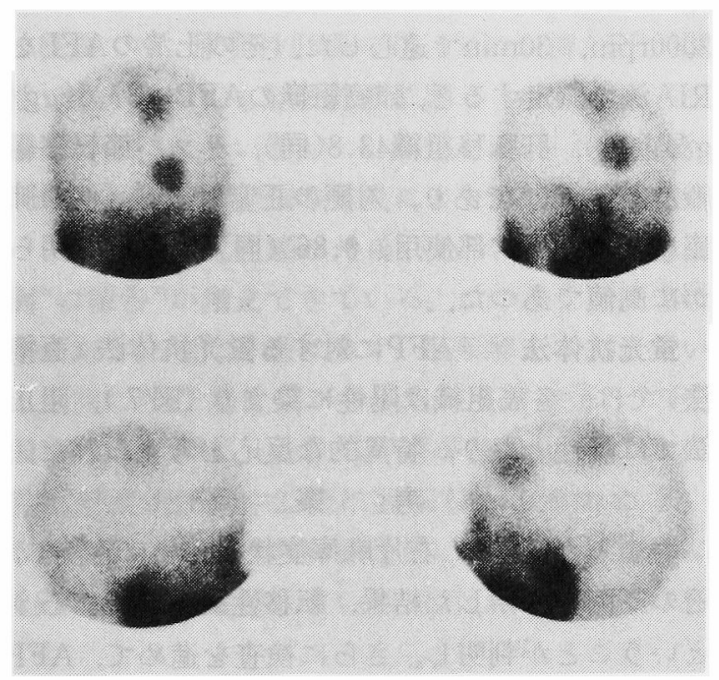

図 3、脳シンチ ${ }^{99}{ }^{\mathrm{m}} \mathrm{TcO}_{4}^{-}$使用)：左前頭葉および頭 頂葉領域にhot noduleあり.

$\mathrm{cm} \times 4 \mathrm{~cm}$ の hot nodule, 左頭頂葉領域にやや辺縁 不明瞭な約 $4 \mathrm{~cm} \times 4 \mathrm{~cm}$ の hot noduleあり．6）脳 血管写 (CAG)（図 4)：左前頭葉と中心瀞附近 にtumor stainあり，7）肝シンチ（図 5)：陰影 欠損, 肝腫大, 肝硬変を疑わせる所見はなかつた。

8）喀痰細胞診： adenocarcinomaを疑わせた。

9）前斜角筋生検：陰性.

臨床経過： 昭和 54 年 8 月頃より右上肢の不全

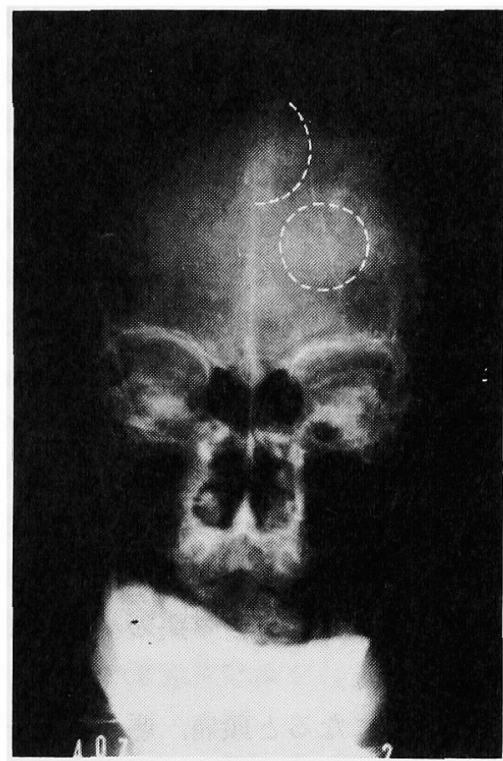

図 4. 左脳血管写。左前頭部之頭頂部にtumor stain （破線部）が認められた。

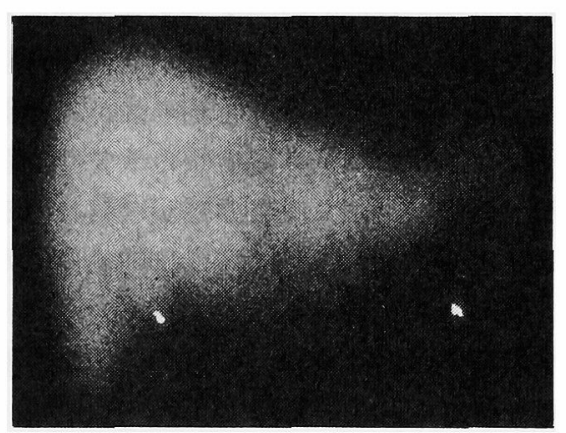

図 5. 肝シンチ ${ }^{99}{ }^{m} \mathrm{~T}$ c使用)：異常所見なし。

麻痺，11月頃より右下肢の不全麻痺が出現し，進 行性に増覀したため, 当科入入院した。

神経学的には，右上下肢の不全麻疸以外に異常 所見は認められない，意識は清明で，前頭葉巣症 状，脳圧六進症状，球麻疸症状などは認められて いない.

CTスキャンによつて, 左前頭葉の領域に周辺が 低密度陰影を示すmass lesionが認められた. 脳腫 瘍の疑いで, CAGを施行した結果, 左CAGでは前 頭葉と頭頂葉にそれぞれtumor stainが認められ た. tumor stainは複数である事, さらには周辺に 
浮腫が著明な事などから，癌の脳転移が考えられ た.胸部X線写真では, retrospectiveにみると縦 隔よりの下肺野に腫瘤状の陰影が認められるが, 入院時には不明であつた。1月に入ると両側肺門 部にも，リンパ節転移と考兄られる畽瘤状陰影が 認められるようになつた。しかし同時期に行なつ た胃透視などでは, 癌を疑わせる所見はなからた。 血清学的検査の中ではAFPのみが, $10000 \mathrm{ng} / \mathrm{ml}$ 上 (PHA法) と高値を示したが，肝シンチでは異 常所見はみられなかつた。1月末になると，Virchowリンパ節も触知されるようになり，2月 5 日 前斜角筋リンパ節生検を行なつた。しか乙異常細 胞はみられず，2 月28日の喀痰の細胞診で初めて 腺癌と診断された。

患者は，2月になると頭痛，悪心，呕吐を訴之 食欲不振となり，3 月中旬には経口摄取が困難に なつてきたため, 中心静脈栄養 (IVH)を施行し た。ついで肝機能もしだいに障害されてきた，脳 圧穴進を防止するために，グリセオール，ステロ イド薬等を，癌に対してはFT 207を，2 月初めか ら使用するなど種々の治療を試みたが，胸部X線 写真所見ならびに脳圧元進症状の改善はみられな かつた。 5 月上旬より呼吸困難が増強し， 5 月 7 日には呼吸停止をおこし，同夜11時30分に死亡し た。

剖検結果： 右肺下葉の中等度分化乳頭型腺癌 が原発と考えられた。転移は両肺, 肝, 脳, 左腎, 食道, 胸腺の実質と, 両肺門, 旁気管, Virchow, 旁胃和よび後腹膜のリンパ節とに見られた。ささ

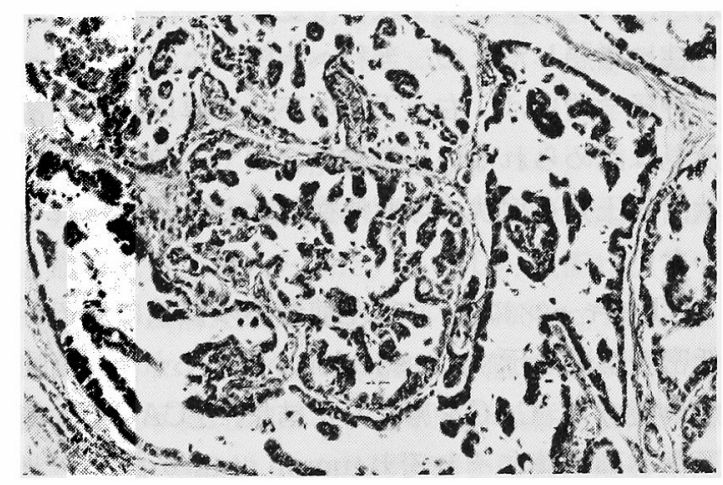

図 6. 癌組織の光顕像. 中等度に分化した乳頭型腺癌.

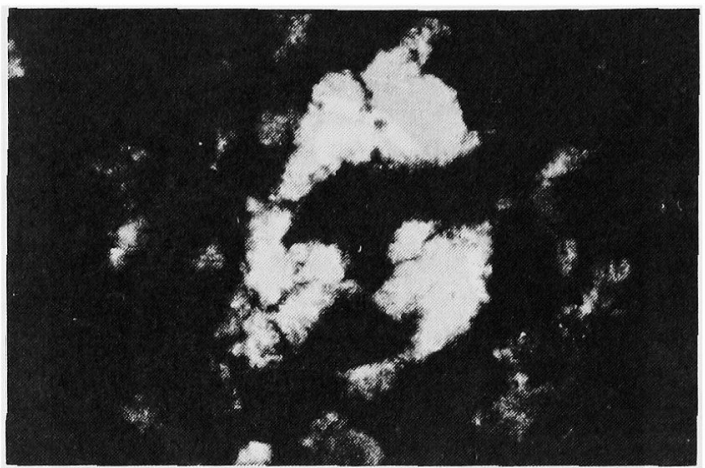

図 7. リンパ節転移部の $\alpha$-fetoprotein䖢光抗体法： 陽性に染まつている.

に肺水腫, 気管支肺炎, 左視床部脳出血, 慢性胆 のら炎, 前立腺炎, 胸水, 悪液質がみられた。

癌組織ならびに正常肝組織のAFP濃度： 約 $2 \mathrm{~g}$ の各組織を $4 \mathrm{cc}$ の生食水でホモジネートし 3000rpm，30minで遠心した. その上清のAFPを RIA法で測定すると, 肺癌組織のAFPは37.6 $(\mu \mathrm{g} /$ g湿重量), 肝転移組織 43.8 (同), リンパ節転移組 織 213.5 (同) であり, 対照の正常肝組織（他の肺 癌患者の肝正常部使用) 0.86 (同) に比べて明ら かに高値であつた。

蛍光抗体法：AFPに対する蛍光抗体法 (直接 法)では, 各癌組織は陽性に染まり(図 7), 阻止 法では陰性となり，特異的な反応と考兄られた。

\section{考案}

著者らの症例は, 右片麻瘏症状のために入院し， その原因を探索した結果，転移珄脳腫瘍であろら といらことが判明し，さらに検查を進めて，AFP 高值を呈した肺原発の腺癌と診断した。

入院時，まず年令などを考慮して，脳血管障害 や変性疾患などを考光た。そこでまず脳のCTス キャンを施行したところ, 左前頭部と頭頂部のと ころにenhanceされる, 周辺部がlow density部分 をもつhigh density areaが証明された。 さらに脳 シンチで, 同部に円形均質なhot noduleが証明さ れ, CAGにても tumor stainを認めた。 以上の事か ら, 脳原発の腫瘍あるいは他からの転移性腫瘍と 考兑た。

そこで，原発巣を探索すべく入念に再検討した 
結果, 胸部 X線像上縦隔陰影・横隔膜陰影に遮敞 された下肺野に，すかててみて初めて識別できる ような卵円形の陰影が見出されだ、脳に複数の睡 瘤がみられることから転移性のものが疑われた。 同時に肺に上記の腫瘤陰影を認めたので，肺原発 の脳転移を伴つた腫湟であろうと結論した。

血清生化学的にはほとんど異常を認めなかつた が，血中AFP值のみ異常な高値を呈した. AFPの 病態生理を考えて原発性肝癌あるいは肝硬变の診 断を考えたが，肝機能ならびに肝シンチでは異常 所見はみい出されなかつた。ここに至つてAFP高 值に対する説明は困難であつた。

AFPは，ヒト胎児血清中に, 1956年Bergstrand ${ }^{5)}$ により発見された。その後Abelev'的動物実験お よび臨床研究により, 血清AFPの高值は原発性肝 癌にかなり特異的である事が判明した。遠藤ら゙ の成績では，原発性肝癌の $76.4 \%$ 血清AFPが陽 性であり，中でも肝細胞癌に限ると87\%の高率で 陽性であつたという。

最近，AFP測定法の普及により，AFP陽泩の一 パトーマ・胎児性癌以外のいわゆる“AFP為陽性 例”の報告7が增えてきている。この多くは消化器 癌であり，特に胃癌に多く，肝転移をきたしてい る症例にAFP陽性例が多いという．加藤ら 国集計によれば，血清AFP值が $1000 \mathrm{ng} / \mathrm{ml}$ 以上の 胃癌剖検例25例中23例に肝転移がみられたとい う。沖田ら ${ }^{\mathrm{B}}$ は虽光抗体法を用いて，胃癌細胞中に AFPの局在確認している。したがつてAFPは肝
特有なむのではなく，他組織においてる産生され 得ることがらかがわれる。

著者らの症例性，原発が肺の腺癌であつてから AFP值が異常に高值を示しているので，肺癌と AFP値の関連について考察してみる.

AFP産生肺癌については，1972年Richard F. Corlin ( $^{9)}$ が, 66才男性の肺の退形成癌の報告を行 なつている。肝転移がみられたが，AFP産生部位 についての検討を行なつていない. 1975年には Tsung ${ }^{10)}$ が，42才の男性で肺小細胞未分化癌の訮 転移例を報告している。彼は，肺癌の肝転移巣周 辺の正常肝細胞がなんらかの影響をらけて, 再生 過程の肝細胞へ变化して, その結果AFPを産生す るのだろらと, 覚光抗体法を行なつて推定してい る.

著者らの症例は，原発が肺で，脳転移が認めら れ，種々の治療にもかかわらず，死の転帰をとつ た。剖検の結果では，右肺下葉原発の中等度分化 乳頭型腺癌であつた。ささらに左肺, 肝, 脳, 腎, 食道, 胸腺などに転移があり，周囲のリンパ節に も転移が認められた。

著者らは, AFPの産生が癌細胞にあるのか, 肝 にあるのかを明らかにするために，次の測定を行 なつた。すなわち, 肺癌組織, 肝転移組織, 周辺 のリンパ節転移組織, 正常肝組織の各組織を, 生 食水と共にホモシネートし，その上清のAFP量 測定した。その結果, 癌組織では, 対照とした正 常肝組織に比して, 明らかに高AFP值を示し, 癌

表 2. 本邦のa-fetoprotein産生肺癌

\begin{tabular}{|c|c|c|c|c|c|c|c|}
\hline 発表者 & 症例 & 原発单 & 組 織 型 & 剖 検 & 血中 $\mathrm{AFP}$ 値 & 組織AFP値 & 螢光抗体法 \\
\hline 小泉 ${ }^{11 \%}$ & 63 才男 & 右肺下䍴 & 末分化癌 & 生存中 & $9,100 \mathrm{ng} / \mathrm{ml}$ & 測定せず & 未施行 \\
\hline 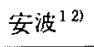 & 67 才男 & 左肺上葉 & 中等度分化型腺癌 & 肝転移(一) & $16.0 \mathrm{mg} / \mathrm{dl}$ & 高 值 & 未施行 \\
\hline 木村 ${ }^{13)}$ & $69 才$ 男 & 右中下胡野 & 大細胞性未分化癌 & 旰転移 $(-)$ & $87,846 \mathrm{ng} / \mathrm{ml}$ & $42,000 \mathrm{ng} / \mathrm{dl}$ & 癌組織踼性 \\
\hline 巟玉 ${ }^{14)}$ & 73才男 & 右肺下葉 & 低分化型腺樒 & 肝転移 $(一)$ & $6,000 \mathrm{ng} / \mathrm{ml}$ & $1,680 \mathrm{ng} / \mathrm{g}$ & 癌組織陽性 \\
\hline 森野 & 67 才男 & 左肺上葉 & 低分化型腺㿋 & 生存中 & $1,552 \mathrm{ng} / \mathrm{ml}$ & 测定せず & 癌組織陽性 \\
\hline 森野 ${ }^{15}$ & 68 才男 & 左肺上葉 & 中等度分化型腺癌 & 肝転移 $(-)$ & $1,600 \mathrm{ng} / \mathrm{ml}$ & $40,000 \mathrm{ng} / \mathrm{dl}$ & 癌組織陽性 \\
\hline 早津 & 68才男 & 右肺下葉 & 中等度分化型腺癌 & 肝転移 $(+)$ & $320,000 \mathrm{ng} / \mathrm{ml}$ & $213.5 \mu \mathrm{g} / \mathrm{g}$ & 癌組織陽性 \\
\hline 横山 ${ }^{16)}$ & 69 才男 & 右下胡野 & 大細胞癌 & 䀒転移 $(-)$ & $88,000 \mathrm{ng} / \mathrm{ml}$ & 高 值 & 癌組織陽性 \\
\hline
\end{tabular}


細胞よりのAFP産生が示唆された。 またAFPに対 する蛍光抗体法を施行すると, 癌細胸では陽性に 染色され，また阻止法によりAFPに特異的なるの であることが知られた，以上の事より著者らは， 肺癌細胞でAFPを産生していると結論づけた。

我国に打いては，1978年の小泉ら ${ }^{11)}$ 発表以来

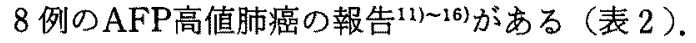
これらはいずれも中等度分化から低分化の腺癌特 よび末分化癌であつた．本症例以外に肝転移は認 めていない,我国の報告では, 癌組織のホモジネー 卜抽出液のAFP高值, AFPに対する蛍光抗体法に よる癌組織陽性などから, 血中AFPの高值の原因 として，癌細胞によるAFP産生を考えている。 た児玉ら ${ }^{14)}$ ，青野ら ${ }^{15}$ 仗好酸性硝子体を癌細胞の 内外に見い出して，それがPalmerのいらAFP， $\alpha_{1}$. antitrypsin, $\alpha_{2}$-macroglobulinの混合物であると 考劣ているが，著者らの症例では，光影で明らか な分泌顆粒は見い出せなかつた。

諸家の報告7によると，AFP陽性癌は，肺，食道， 胃, 肝, 胆のう, 荤, 十二指腸などの内胚葉の前 腸由来のもの之, 中胚葉由来の卵巣からのものと に集中して拈り, 中腸, 後腸由来の器官からの癌 や, 外胚葉系由来の器官からの癌, あるいは肉腫 からはまつたくみられていないという，著者らの 症例も，この見解に合致するものであつた。

$$
\text { おわりに }
$$

本症例は脳症状を初発とした極めて希なAFP 産生肺癌であり，内外に拉ける今日までの若干の 文献的考察を加壳て報告した。

\section{文献}

1) Abelev GI: Alpha-fetogloblin in ontogenesis and its association with malignant tumors.
Advances in Cancer Res $14: 295,1971$.

2) Tatarinov YS: Detection of embryospecific $\alpha$-globlin in the blood sera of patient with primary liver tumor. Vop med Klim 10:90, 1964.

3）赤井貞彦，他：いわゆる“ $\alpha$-fetoprotein㑇陽性例” の検討一とくに $\alpha$-fetoprotein陽性癌について一。 内科 $30: 230,1972$.

4）下里幸雄：木ルモン，酥素の異常分淰，新内科学 大系28A肺腫湟。中山書店, 東京, 1977, p204.

5) Bergstrand CG and Czar B : Detction of a new protein fraction in serum from the human fetus. Scand J Clin Lab Invest $9:$ 178, 1956.

6）遠藤康夫，他： $\alpha_{1}$-Fetogloblink上る原発性肝癌 の診断。肝臓 $10: 143,1969$.

7）加藤 清, 他：一パト一マ・悪性奇形腫以外の $\alpha$ Fetoprotein陽性癌についての考察一全国調査結 果を中心として一。癌の臨床 $20 ： 376,1974$.

8）沖田極，他：上卜胃癌細胞に括ける $\alpha$-Fetoproteinの局在について. 医学のあゆみ $99: 797$, 1976.

9) Corlin RF and Tompkins RK: Serum alphafetogloblin in a patient with hepatic metastases from bronchogenic carcinoma. Amer J Dig Dis $17: 553,1972$.

10) Tsung SH: Alpha-fetoprotein in lung cancer metastatic to the liver. Arch Pathol 99: 267, 1975.

11）小泉 潔，他：肺末分化癌でAFP異常高值を呈乙 た一例について (抄録). 肺渻 $18: 438,1978$.

12）安波礼子, 他： $\alpha$-fetoprotein産生肺癌の 1 症例 (抄録)。肺癌 $19: 96,1979$ 。

13）木村文治，他： $\alpha$-Fetoprotein産生未分化癌の 1 剖検例（抄録）。日内会誌 $70: 446 ， 1981$.

14）児玉哲郎，他： $\alpha$-Fetoprotein産生肺癌の1例(抄 録)。肺癌 Suppl. 85，1980.

15）森野英男，他：AFP高値を呈した肺癌の 2 症例 (抄録)。肝癌 Suppl. 86, 1980 。

16）横山和敏，他： $\alpha$-Fetoprotein (AFP) 産生肺癌の 1 剖検例 (抄録). 肺癌 $21: 101,1981$. 